Original Article

\title{
Thalassemia, a human blood disorder
}

\author{
Talassemia, uma doença do sangue humano
}

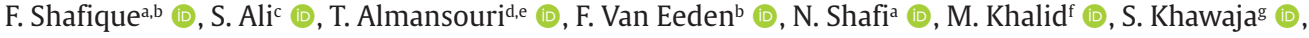 \\ S. Andleeb ${ }^{\mathrm{a}}$ (D) and M. ul Hassan ${ }^{\mathrm{h}}$ (D) \\ aUniversity of Azad Jammu and Kashmir, Faculty of Science, Department of Zoology, Muzaffarabad, Pakistan \\ bUniversity of Sheffield, Faculty of Science, Department of Biomedical Science, Sheffield, United Kingdom \\ 'Government College University Lahore, Faculty of Science, Department of Zoology, Applied Entomology and Medical Toxicology Laboratory, \\ Lahore, Pakistan \\ dUniversity of Sheffield, Sheffield Institute for Translational Neuroscience - SITraN, Department of Neuroscience, Sheffield, United Kingdom \\ eKing Abdulaziz University, Department of Applied Medical Science (Medical Laboratory), Jeddah, Saudi Arabia \\ fWomen University of Azad Kashmir, Department of Biotechnology, Bagh, Azad Kashmir, Pakistan \\ sUniversity of Azad Jammu and Kashmir, Department of Biotechnology, Muzaffarabad, Pakistan \\ hUniversity of Sheffield, Faculty of Science, Department of Molecular Biology and Biotechnology, Sheffield, United Kingdom
}

\begin{abstract}
A group of inherited blood defects is known as Thalassemia is among the world's most prevalent hemoglobinopathies. Thalassemias are of two types such as Alpha and Beta Thalassemia. The cause of these defects is gene mutations leading to low levels and/or malfunctioning $\alpha$ and $\beta$ globin proteins, respectively. In some cases, one of these proteins may be completely absent. $\alpha$ and $\beta$ globin chains form a globin fold or pocket for heme (Fe++) attachment to carry oxygen. Genes for alpha and beta-globin proteins are present in the form of a cluster on chromosome 16 and 11, respectively. Different globin genes are used at different stages in the life course. During embryonic and fetal developmental stages, $\gamma$ globin proteins partner with $\alpha$ globin and are later replaced by $\beta$ globin protein. Globin chain imbalances result in hemolysis and impede erythropoiesis. Individuals showing mild symptoms include carriers of alpha thalassemia or the people bearing alpha or beta-thalassemia trait. Alpha thalassemia causes conditions like hemolytic anemia or fatal hydrops fetalis depending upon the severity of the disease. Beta thalassemia major results in hemolytic anemia, growth retardation, and skeletal aberrations in early childhood. Children affected by this disorder need regular blood transfusions throughout their lives. Patients that depend on blood transfusion usually develop iron overload that causes other complications in the body systems like renal or hepatic impairment therefore, thalassemias are now categorized as a syndrome. The only cure for Thalassemias would be a bone marrow transplant, or gene therapy with currently no significant success rate. A thorough understanding of the molecular basis of this syndrome may provide novel insights and ideas for its treatment, as scientists have still been unable to find a permanent cure for this deadly disease after more than 87 years since it is first described in 1925.
\end{abstract}

Keywords: thalassemias, beta globin genes, hemoglobinopathies.

\begin{abstract}
Resumo
Um grupo de defeitos sanguíneos hereditários é conhecido como talassemia e está entre as hemoglobinopatias mais prevalentes do mundo. As talassemias são de dois tipos, como talassemia alfa e beta. As causas desses defeitos são as mutações genéticas que levam a níveis baixos e/ou proteínas de globina com mau funcionamento, respectivamente. Em alguns casos, uma dessas proteínas pode estar completamente ausente. As cadeias de globina $\alpha$ e $\beta$ formam uma dobra ou bolsa de globina para a fixação de heme $(\mathrm{Fe}++)$ para transportar oxigênio. Os genes das proteínas alfa e beta globina estão presentes na forma de um cluster nos cromossomos 16 e 11, respectivamente. Diferentes genes de globina são usados em diferentes estágios do curso de vida. Durante os estágios de desenvolvimento embrionário e fetal, as proteínas $\gamma$ globina se associam à $\alpha$ globina e, posteriormente, são substituídas pela proteína $\beta$ globina. Os desequilíbrios da cadeia de globina resultam em hemólise e impedem a eritropoiese. Indivíduos que apresentam sintomas leves incluem portadores de talassemia alfa ou as pessoas com traços de talassemia alfa ou beta. A talassemia alfa causa condições como anemia hemolítica ou hidropsia fetal fatal, dependendo da gravidade da doença. A beta talassemia principal resulta em anemia hemolítica, retardo de crescimento e aberrações esqueléticas na primeira infância. As crianças afetadas por esse distúrbio precisam de transfusões de sangue regulares ao longo da vida. Os pacientes que dependem de transfusão de sangue geralmente desenvolvem sobrecarga de ferro que causa outras complicações nos sistemas do corpo, como insuficiência renal ou hepática, portanto as talassemias
\end{abstract}

*e-mail: muhassan1@sheffield.ac.uk; microkust@gmail.com

Received: November 29, 2020 - Accepted: April 2, 2021 
agora são classificadas como uma síndrome. A única cura para as talassemias seria um transplante de medula óssea ou terapia genética sem atualmente uma taxa de sucesso significativa. Uma compreensão completa da base molecular dessa síndrome pode fornecer novos insights e ideias para seu tratamento, já que os cientistas ainda não conseguiram encontrar uma cura permanente para essa doença mortal depois de mais de 87 anos desde que foi descrita pela primeira vez em 1925.

Palavras-chave: thalassemias, genes da beta globina, hemoglobinopatias.

A dentist named Cooley first reported a progression of iron deficiency in infants leading to splenomegaly and bone deformation soon after their birth in 1925 (Cunningham, 2010).

In 1932, Whipple and Bradford explained the pathology of the disease for the first time, and as most of the patients were found to be native to the Mediterranean range, they termed the condition as "thalassemia" (Rachmilewitz and Giardina, 2011).

Blood disorder types characterized by low levels or missing normal globin chains in the normal red blood cell protein hemoglobin are now characterized as thalassemia. There are four types of globin chains present named alpha $(\alpha)$ beta $(\beta)$ gamma $(\gamma)$ and delta $(\delta)$. Depending on which chain production is disturbed, the thalassaemias are termed as $\alpha-, \beta-, \gamma-, \delta-, \delta \beta-$, or $\varepsilon \gamma \delta \beta$-thalassaemias. Mostly inherited as a recessive trait, the most common types are $\alpha$ - and $\beta$-thalassaemias, that result from the deficiency of $\alpha$ - or $\beta$-globin proteins that are necessary for the production of normal hemoglobin molecule (HbA, $\alpha 2 \beta 2)$ in an adult human (Taher and Cappellini, 2014).

As defined, thalassemia is a complex of various hereditary disorders of hemoglobin combination featuring insufficient production of at least one of the globin chains driving imbalanced globin-chain production, damaged hemoglobin eventually causes anemia (Cappellini et al., 2014). Hemoglobin is a metalloprotein ( $\mathrm{Hb}$ or $\mathrm{Hgb}$ ) found inside the red blood cells (RBCs) of all the vertebrates (except a fish family Channichthyidae) and some invertebrates, functions as an oxygen-transporting vehicle (Burmester and Hankeln, 2014).

Inside the blood, hemoglobin acts as a carrier that conveys oxygen from lungs or gills to entire body tissues and upon reaching there, it unloads the oxygen that in turn is used in aerobic respiration to produce ATPs to run the metabolic processes of an organism (Zhao et al., 2019).

A hemoglobin molecule inside the mammalian RBCs could bind up to four oxygen molecules at a time, which in turn increases the blood oxygen binding capacity (OBC) seventy times, as the $\mathrm{OBC}\left(\mathrm{C}_{\mathrm{Hb}}\right)$ of hemoglobin alone is 1.34 $\mathrm{O}_{2} \mathrm{~mL} / \mathrm{gm} \mathrm{Hb}$ (Ali, 2018). Some amount of oxygen may also dissolve directly into the blood during respiration but that is only $1.5 \%$ of total oxygen carried through the blood (Molnar and Gair, 2013).

Hemoglobin is involved in transporting other gases too, it binds a portion of carbon dioxide $\left(\mathrm{CO}_{2}\right)$ gas which is produced as a result of metabolic activities, in the form of carbaminohemoglobin, i.e., hemoglobin loaded with $\mathrm{CO}_{2}$, and contributing a fraction of $20-25 \%$ of the total $\mathrm{CO}_{2}$ exhaled (Hughes and Pride, 2012). Hemoglobin additionally carries nitric oxide (NO), which an essential regulatory molecule, NO is bound to a thiol group of globin protein, discharging along with oxygen (Biagioli et al., 2009).
Hemoglobin is not only confined to the red blood cells (RBCs) but it can also be found in progenitor cells of $\mathrm{RBC}$, dopaminergic neurons of group A9 present in the ventrolateral midbrain of some rodents and primates, macrophages, cells of alveoli, and mesangial cells supporting the glomerular tuft inside the kidney are the other cells which contain hemoglobin. In these tissues, hemoglobin functions as an antioxidant and metabolic regulator to some extent rather than an oxygen supplier (Hughes and Pride, 2012).

The functional, practical exercises performed by hemoglobin other than gas transport include fertilization, signaling, adjustment of inflammatory reactions to defend and protect the cell. These exercises are proficiently executed while $\mathrm{Hb}$ is sequestered securely inside the boundaries of the RBCs. Outside the RBC limits, Hb disaggregates and jeopardizes the cell life as in severe cases, antioxidants become overwhelmed to clear free radicals that are produced during Hb oxidation (Mairbäurl and Weber, 2012).

Hemoglobin is a protein with four polypeptide subunits with 64,500 Da molecular weight. It consists of two $\alpha$ - and two $\beta$-chains of 141 and 146 amino acids each, respectively (Figure 1). In adults, the hemoglobin's secondary structure of all polypeptide chains is mainly $\alpha$-helical. HbA does not contain any $\beta$-strands or disulfide bonds. Unusually, it also lacks isoleucine. The $\beta$-chain of HbA comprises eight helical fragments, designated by letters $\mathrm{A}-\mathrm{H}$. The $\alpha$-chain is quite similar but lacks helix D. Each polypeptide chain of $\mathrm{HbA}$ maintains a three-dimensional conformation, known as globin fold, just like a closely related monomeric protein, myoglobin (Mb). The globin fold is, in fact, an arrangement of helices due to which a cavity is formed that holds and attaches to a heme ( $\mathrm{Fe}++)$ prosthetic group. A covalent bond is present between the $\mathrm{N}_{\varepsilon 2}$ atom of the F8His residue and the heme iron inside each polypeptide of the globin subunits. This heme/iron atom that is in the ferrous state has the potential to reversibly bind with specific gas ligands

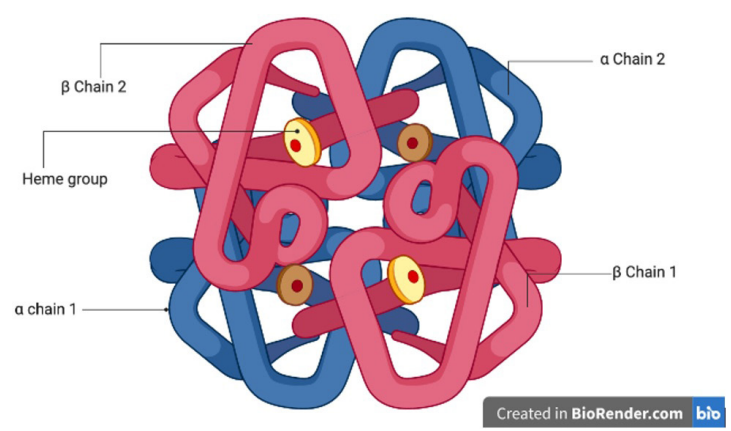

Figure 1. Ultrastructure of the hemoglobin molecule. 
like oxygen, carbon monoxide, and nitric oxide (Hassan and Alhajouj, 2011). As already mentioned, hemoglobin comprises two $\alpha$ and two $\beta$-chains. Therefore, it can be said that it is a dimer of alpha-beta dimers ( $\alpha \beta$ dimers). The $\alpha_{1} \beta_{1}$ and $\alpha_{2} \beta_{2}$ dimers are connected by a 2 -crease pivot of symmetry. The interfaces of subunits $\alpha_{1} \beta_{1}$ and $\alpha_{2} \beta_{2}$ are identical, and $\alpha_{1} \beta_{2}$ and $\alpha_{2} \beta_{1}$ subunit interfaces are mirror images of each other (Hamamy and Al-Allawi, 2013).

The human embryo and fetus normally develop with different hemoglobin variants i.e., Hb Portland-1 ( $\zeta 2 \gamma 2)$, Hb Gower-1 ( $\zeta 2 \varepsilon 2)$, Hb Gower-2 ( $\alpha 2 \varepsilon 2)$ and fetal Hb or HbF $(\alpha 2 \gamma 2)$ (Kohne, 2011). Stage-specific combinations of globin genes are transcribed within the fetus during gestation, which leads to producing various forms of hemoglobin molecules such as several embryonic hemoglobins, hemoglobin $\mathrm{A}(\mathrm{HbA})$ and, hemoglobin $\mathrm{F}(\mathrm{HbF})$ (Shown in Table 1). Immature erythrocytes produce the embryonic hemoglobins (Gower 1, Gower 2, and Portland) in the yolk sac. They persist up to the $12^{\text {th }}$ week of pregnancy. In the fifth week, Hemoglobin F (Hb F) appears which predominates during fetal life. $\mathrm{Hb} F$ is synthesized initially in the liver of the fetus and remains there for several weeks after birth. HbA prevails after birth, which originates in the bone marrow. Most common among other variants is Hemoglobin A ( $\alpha 2 \beta 2$ ) usually with an amount of around $95 \%$ (Kaufman et al., 2021). The normal range of hemoglobin A2 ( $\alpha 2 \delta 2)$ is $1.5-3.5 \%$ of the total hemoglobin in an adult. Though $\mathrm{Hb}$ A2 has no physiological importance in an adult its level may rise in case of alpha or beta chain reduction (Figueiredo, 2015) the mutations in delta globin genes along with beta-globin gene variations may also interfere with the beta-thalassemia diagnosis especially in the cases of beta-thalassemia trait (Hariharan et al., 2016). The gamma chain is synthesized late in the last trimester and at this stage, the $\mathrm{Hb} F(\alpha 2 \gamma 2)$ is only restricted in a small number of RBCs known as 'F-cells'. Interestingly, in individuals having sickle cell anemias and beta-thalassemia, the $\mathrm{Hb}$ F level is quite elevated (Kaufman et al., 2021).

All genetic hemoglobin disorders fall under the broad term "hemoglobinopathy". These are split further into two main categories, which are:

Table 1. Various globin genes and their subunits.

\begin{tabular}{|c|c|c|c|}
\hline Subunit & Gene & Chromosome & Expression \\
\hline \multirow[t]{2}{*}{$\zeta$-Globin } & $\mathrm{HB} \zeta 1$ & 16 & Embryonic \\
\hline & $\mathrm{HB} \zeta 2$ & & \\
\hline \multirow[t]{2}{*}{$\alpha$-Globin } & $\mathrm{HB} \alpha 1$ & 16 & $\begin{array}{l}\text { Fetal and } \\
\text { adult }\end{array}$ \\
\hline & $\mathrm{HB} \alpha 2$ & & \\
\hline$\varepsilon$-Globin & $\mathrm{HB} \varepsilon$ & 11 & Embryonic \\
\hline \multirow[t]{2}{*}{ y-Globin } & HBG1 (Ay) & 11 & Fetal \\
\hline & HBG2 (Gy) & & \\
\hline$\beta$-Globin & HBB & 11 & Adult \\
\hline$\delta$-Globin & HBD & 11 & Adult \\
\hline
\end{tabular}

- Thalassemia syndromes (resulting in severe anemia and other related complications);

- Structural variants of hemoglobin (malfunctioning hemoglobin proteins).

Both occur due to mutated and deleted segments of $\alpha$ - or $\beta$-globin genes. Thalassemia is caused due to defects in the globin genes, which results in Hb synthesis disorders i.e., under or overproduction of globin chains. The structure of Hemoglobin in such cases remains normal. Abnormal hemoglobin only occurs when there is a change in the structure of $\mathrm{Hb}$. There are many combinations of both forms like $\beta^{0} / \beta^{+}$-thalassemias, $\mathrm{Hb} /$ Sickle disease, and $\mathrm{HbE} / \alpha$-thalassemias. The conventional capabilities of the pathophysiology and various ailment patterns are restrained, resulting in limited possibilities to summarize them (Giardine et al., 2014).

The pathogenic hemoglobin protein also indicates the cells and organ types before and after birth in which it is originated (Table 2) (Mehdi and Al Dahmash, 2011; De Sanctis et al., 2017). Based on the affected globin chain, the thalassemias are arranged into alpha $(\alpha)$ or beta $(\beta)$ types. The $\beta$ thalassemia is found throughout the world while $\alpha$ thalassemia is more prevalent in the Mediterranean region, (Lippi and Mattiuzzi, 2020, De Sanctis et al., 2017) and China (Qin and Wu, 2009; Muncie Junior and Campbell, 2009).

\section{Alpha Thalassemia}

There are 2 copies of the alpha-globin gene in the human genome both located on chromosome 16, therefore in a normal diploid cell, 4 copies of the gene are available, to produce the protein. Alpha-thalassemia is caused by an underproduction of $\alpha$-globin proteins due to mutation or deletion of one of the four $\alpha$ globin genes (Leung and Lao, 2012).

There are two phenotypes of $\alpha$ thalassemia recorded so far. $\alpha$ thalassemia I or minor and $\alpha$ thalassemia II with no clinical symptoms of thalassemia. It is now known that $\alpha$ thalassemia I is associated with the complete absence of $\alpha$ globin proteins and the other is merely a reduction in $\alpha$ globin expression. These two $\alpha$ thalassemia variants are now designated as thalassemia $\alpha^{\circ}$ and thalassemia $\alpha^{+}$, respectively as shown in Table 3 (Haley, 2017).

Alpha (0) thalassemia - there are more than 20 different mutations described, resulting in the deletion of all the sets of $\alpha$-globin genes. People having this deficiency are unable to synthesize normal $\alpha$-globin and therefore cannot make any normal functioning A, F, or A2 hemoglobin. This prompts the onset of hydrops fetalis or "hemoglobin Bart"; children born with this disorder do not survive outside the uterus.

Alpha (+) thalassemia -more or less fifteen genetic mutations are reported, which result in limited $\alpha$-globin protein synthesis generally because of the functional deletion of at least one alpha-globin gene.

Alpha (+) thalassemia is further sub-classified into four categories: 
Table 2. Types of Combination Hemoglobinopathies.

\begin{tabular}{|c|c|c|}
\hline No. & Type of hemoglobinopathy & No. of $a$ and $b$ chains present \\
\hline 1. & Hemoglobin D-Punjab - ( $\alpha 2 \beta D 2)$ : & one alpha, two betas, and one delta globin polypeptide chains. \\
\hline 2. & Hemoglobin $H$ - ( $\beta 4)$ : & $\begin{array}{l}\text { four } \beta \text { chains, might also be present in various types of } \alpha \text { lpha } \\
\text { thalassemia }\end{array}$ \\
\hline 3. & Hemoglobin Barts $-(\gamma 4)$ & four $\gamma$ chains, may also present in $\alpha$ thalassemia variants. \\
\hline 4. & Hemoglobin $S-(\alpha 2 \beta S 2)$ & $\begin{array}{l}\text { observed in individuals having sickle cell anaemia. A point mutation in } \\
\text { the } \beta \text {-chain gene modifies the characteristics of haemoglobin, }\end{array}$ \\
\hline 5. & Hemoglobin $\boldsymbol{C}(\alpha 2 \beta C 2)$ & $\begin{array}{l}\text { causes due to a change in the } \beta \text {-chain gene sequence results in a mild } \\
\text { chronic hemolytic anaemia. }\end{array}$ \\
\hline 6. & Hemoglobin $\boldsymbol{E}(\alpha 2 \beta \mathrm{E} 2)$ & $\begin{array}{l}\text { A haemoglobin variant with the mutant } \beta \text {-chain gene causes anemia due } \\
\text { to a slight chronic red cell hemolysis. }\end{array}$ \\
\hline 7. & Hemoglobin /(AS) & $\begin{array}{l}\text { characterized by sickle cell trait and occurs due to the hybrid gene } \\
\text { comprises of an adult and a sickle cell disease allele. }\end{array}$ \\
\hline 8. & Hemoglobin SC disease & $\begin{array}{l}\text { A complex heterozygous hemoglobin having a gene causes sickle red } \\
\text { cells, and the other encodes for Hemoglobin C [17]. }\end{array}$ \\
\hline
\end{tabular}

Table 3. Thalassemia Syndromes and Genotypes.

\begin{tabular}{|c|c|c|c|c|}
\hline Alpha Thalassemia & $\alpha$ genes & Globin Chains & Hemoglobin & Anemia \\
\hline Normal & $\alpha \alpha / \alpha \alpha$ & $\alpha^{2} \beta^{2}$ & A & None \\
\hline Silent Carrier & $\alpha \alpha / \alpha-$ & $\alpha^{2} \beta^{2}$ & A & None \\
\hline Trait & $\alpha-/ \alpha-$ OR $--/ \alpha \alpha$ & $\alpha^{2} \beta^{2}$ & A & Mild \\
\hline Hb H disease & $--\mid-\alpha$ & $\alpha^{2} \beta^{2} \cdot \beta^{4}$ & $\mathrm{~A}, \mathrm{H}$ & Intermediate \\
\hline \multirow[t]{2}{*}{ Hydrops fetalis } & $--\mid--$ & $\gamma^{4}$ & Barts & Lethal \\
\hline & & $\zeta^{2} \gamma^{2}$ & Portland & \\
\hline Beta Thalassemia & $\beta$ genes & Globin Chains & Hemoglobin & Anemia \\
\hline Normal & $\beta / \beta$ & $\alpha^{2} \beta^{2}$ & A & None \\
\hline Thalassemia minor & $\beta^{+} / \beta$ OR $\beta^{0} / \beta$ & $\alpha^{2} \beta^{2}, \alpha^{2} \delta^{2}, \alpha^{2} \gamma^{2}$ & A & None \\
\hline \multirow[t]{2}{*}{ Thalassemia major } & $\beta^{+} / \beta^{+} \mathrm{OR}$ & $\alpha^{2} \beta^{2}, \alpha^{2} \delta^{2}, \alpha^{2} \gamma^{2}$ & $\mathrm{~A}, \mathrm{~A} 2, \mathrm{~F}$ & Severe \\
\hline & $\beta^{0} / \beta^{0}$ & $\alpha^{2} \delta_{2}, \alpha^{2} \gamma^{2}$ & & Severe \\
\hline *HPFH & $\gamma / \gamma$ & & $\mathrm{F}$ & Mild \\
\hline
\end{tabular}

${ }^{*}$ Hereditary Persistence of Fetal Hemoglobin.

A- Thalassemia $(-\alpha / \alpha \alpha)$ occurs when three out of four functional $\alpha$-genes are inherited. The individuals are referred to as asymptomatic carriers for $\alpha$-thalassemia. Various terms used for this disorder are "alpha thalassemia minima", "alpha thalassemia-2 trait", and "heterozygosity for alpha (+) thalassemia minor". These carriers are clinically normal or may have mild anemia;

B- Thalassemia $(-\alpha /-\alpha)$ condition is known as a transdeletion because two healthy alpha genes are inherited, one from each of the two chromosomes $(-\alpha /-\alpha)$ whereas homozygosity for alpha (+) thalassemia $(\alpha \alpha /--)$ (two on the same chromosome) is known as a "cis deletion" resulting in "alpha thalassemia minor" or "alpha thalassemia-1 trait". Parents who are carriers of the cis deletion can have one out of four (25\%) babies affected with alpha thalassemia major in every pregnancy;

C- Hemoglobin H: when only one healthy alpha gene $(-\alpha /--)$ is inherited, it results in the massive production of hemoglobin $\mathrm{H}(\mathrm{Hb} \mathrm{H})$ comprising tetramers of surplus beta chains. The disorder is named "Hb H disease";

D- Hemoglobin Bart's disease: When all four alpha genes are lost, a situation occurs, that is life-threatening. Four gamma-globin chains are formed during the life of the fetus inside the womb which unites to frame irregular hemoglobin known as 'hemoglobin Bart's' (Camacho et al., 1999).

Alpha thalassemia is different from beta-thalassemia in its pathophysiology. The shortage of $\alpha$ chain results in excess production of gamma or beta chains, which form Hb Bart's 
and $\mathrm{Hb} \mathrm{H}$, respectively. These dissolvable tetramers do not accumulate in the bone marrow, and thus erythropoiesis is more viable as compared with $\beta$-thalassemia. In any case, $\mathrm{Hb} \mathrm{H}$ is not only unstable but also accumulate in red cells with time. Inclusion bodies created in this way are caught in the spleen and different parts of the microcirculation prompt to reduce red cell survival. Furthermore, both $\mathrm{Hb}$ Barts and $\mathrm{Hb} \mathrm{H}$ have a very high oxygen affinity; because they have no $\alpha$ chains, there is no heme-heme interaction and their oxygen dissociation curves resemble myoglobin (Taher et al., 2018). In conclusion, there are Four subtypes of alpha thalassemia are there ranging from moderate to severe in their effects on the patient's body (Lee et al., 2010).

\subsection{Alpha thalassemia minor}

It is an asymptomatic carrier condition that occurs due to the deletion of the one $\alpha$ - globin gene. This condition usually causes no symptoms or signs of anemia and does not need treatment due to negligible alpha protein deficiency; therefore, the hemoglobin appears to be normal (Leung and Lao, 2012). The term "silent carrier" is usually used to describe this condition because it is not easily diagnosed through standard hematological investigations. Only DNA analysis could detect this condition (Camacho et al., 1999).

\subsection{Alpha thalassemia trait}

The trait is also known as mild alpha-thalassemia. The patients are deficient in two alpha-globin genes. The affected individuals have RBCs smaller than usual and are mildly anemic but do not show any symptoms and may only be diagnosed by routine tests (Leung and Lao, 2012).

\subsection{Alpha thalassemia intermedia}

Also, it is known as hemoglobin $\mathrm{H}$ disease. Individuals lacking three alpha globin genes become severely anemic and mostly cannot survive without blood transfusion. Newborns who inherited alpha thalassemia intermedia seem healthy at birth but mainly develop anemia and splenomegaly as they approach the second year of his life. Hepatomegaly is not commonly reported, and there might be some relationship to the mental retardation in affected individuals. As hemolysis occurs in this type of anemia the tendency to develop respiratory infections, gallstones, and leg ulcers increases. Bone deformities are not usually found in hemoglobin H disease (Lee et al., 2010).

The imbalanced alpha and beta chain synthesis (that is usual) induces aggregation of beta chains inside the RBCs. Usually, beta chains are coupled with alpha chains only. Alpha thalassemia with three-gene deletions causes the beta chains to accumulate in gatherings of four, creating unusual hemoglobin, called "hemoglobin $\mathrm{H}$ ". This condition leads to "hemoglobin H disease". This hemoglobin variant has two issues. First, it does not convey oxygen efficiently, making it practically useless to the cell. Secondly, hemoglobin $\mathrm{H}$ protein harms the cell membranes of RBCs, accelerating cell death. A combination of reduced alpha chain synthesis and red cell lysis in hemoglobin $H$ disease creates severe and fatal anemia. Without treatment, most individuals do not survive and expire in their early teens or before (Camacho et al., 1999).

\subsection{Alpha thalassemia major}

"Hydrops fetalis" or alpha thalassemia major is a condition in which no alpha genes are found in the patients' genome, resulting in four gamma-globin chains production by the fetus that produces malfunctioning hemoglobin known as hemoglobin Bart's. Most affected individuals having Hemoglobin Bart's cannot survive or otherwise die in just a few hours after birth (Lee et al., 2010).

Alpha thalassemia with four deletions in the gene has rarely been diagnosed in the uterus, especially in a family with a history of the disorder occurring in early childhood. Reportedly, some of these children have been saved through blood transfusions during pregnancy (Camacho et al., 1999).

\section{Beta Thalassemia}

Around 200 mutations of the beta-globin gene have been identified worldwide which produce beta-thalassemia. Unlike alpha thalassemia syndromes where deletion is usually the root cause, beta-thalassemia occurs due to mutations that influence all stages of beta-globin protein synthesis including transcription, translation, and beta-globin production durability. Two types of $\beta$-thalassemia, $\beta^{+}$, and $\Omega^{\circ}$ thalassemia are identified so far that lack beta chain production altogether (Table 1 ). Beta thalassemia major usually results when $\beta^{+}$or $\beta^{\circ}$ thalassemia occurs in homozygous condition. Occasionally, however, the compound heterozygous state for both $\AA^{+}$ and $\beta^{\circ}$ thalassemia results in beta-thalassemia. In the case of homozygous $\beta^{\circ}$ thalassemia, there is no $\mathrm{Hb} \mathrm{A}$, an abundance of $\mathrm{HbF}$, and variable amounts of $\mathrm{Hb} \mathrm{A} 2$. In individuals with homozygous $\mathrm{B}^{+}$thalassemia, the amount of $\mathrm{Hb} \mathrm{A}$ is variable, $\mathrm{Hb} \mathrm{F}$ is increased and distributed heterogeneously among RBCs whereas $\mathrm{Hb}$ A2 is normal, decreased, or elevated (Taylor et al., 2012).

The molecular variations in $\beta$ thalassemia result in missing or diminished $\beta$ chain generation. Alpha chain Synthesis remains unaffected, and therefore there is an unequal amount of globin chain generation that prompts an abundance of $\alpha$ chains. They are not stable in the absence of their normal partners and precipitate in the RBC precursors, which interferes with RBC processing. As a result, there is a variable level of intramedullary destruction of RBCs precursors (i.e. ineffective erythropoiesis). The RBCs having $\alpha$ chain incorporated when enter the bloodstream interfere with their segment via microcirculation, exclusively in the spleen. Such cells demonstrate a high variability in the structure of membrane and penetrability and are short-lived. Hence, anemia occurs due to both abnormal erythropoiesis and shortened cell survival. The anemia stimulates erythropoietin production resulting in bone marrow expansion, which consequently causes deformed skull and large bones ref needed. Since the spleen is overburdened and required to remove a continuous stream of abnormal red cells, enlarges before it exhausts ultimately (Borgna-Pignatti and Gamberini, 2011).

Generally, three categories of beta-thalassemia have been recognized, ranging from mild to severe by affecting the patient's body. 


\subsection{Beta thalassemia minor}

Also known as thalassemia trait due to one of malfunctioning beta-globin genes, but this generally causes no significant problem in the proper functioning of hemoglobin protein (Hay and Weatherall, 2017). When there is an excess of alpha chains, the mechanism that switches off gamma chain expression does not work effectively, thus the levels of $\mathrm{Hb} \mathrm{F}$ remain somewhat elevated in these patients. The alpha chains consolidate with the accessible beta chains bringing about diminished levels of hemoglobin rest of the surplus alpha chains empower the over-production of delta chains (Jha and Jha, 2014) Affected individuals have a 1:1 chance to pass the thalassemia minor trait to their child (Memon, et al., 2017)

\subsection{Beta thalassemia intermedia}

A condition where the absence of beta polypeptide in the hemoglobin is sufficient to bring about more extreme anemia and serious medical issues, including shortness of breath, bone disfigurements, mild jaundice, and an enlarged spleen. The condition is characterized by having two abnormal genes in affected individuals while still producing some beta-globin. Depending on the level and functional competence of beta-Globin is a broad range in the clinical severity of this disease (Hay and Weatherall, 2017).

\subsection{Beta thalassemia major}

It is also known as "Cooley's anemia" and is the most severe form of beta-thalassemia with absent beta-globin synthesis thus preventing the production of significant amounts of $\mathrm{Hb} \mathrm{A}$. The severe irregularity of globin chain synthesis (alpha >> beta) brings about extreme microcytic hypochromic anemia. Within the RBCs surplus unpaired alpha-globin chains precipitate, this harms the plasma membranes of RBCs and brings about intravascular hemolysis. Besides, premature death/apoptosis/lysis/ necrosis of erythroid precursors reduces the number of RBCs even further. The severe anemia results in hypoxia and the resulting EPO causes hyperplasia in the bone marrow and will lead to extramedullary hematopoiesis (Cunningham, 2010).

During childbirth, the infant with thalassemia major appears to be healthy. This is because there is a predominance of fetal hemoglobin ( $\mathrm{Hb} \mathrm{F})$ during gestation. which lacks any beta chains. Anemia starts to appear a few months after birth, as the infant switches over from gamma to beta globulin. The infant's growth retards and often has issues (due to poor oxygen absorbance in the body with significant anemia), episodes of fever to which the severe sickliness inclines the small stature, slow bowel movement, and other intestinal issues. If untreated, it will cause the enlargement of organs like the spleen, liver, and heart, and bones to become weak and brittle. The condition results in death before age twenty (Hay and Weatherall, 2017).

Regular blood transfusions and extensive continuous therapeutic care are required throughout life in this type of anemia. After some time, these successive transfusions prompt iron overload in the body. Without treatment, this overabundant iron will be stored in the liver, heart, spleen, and other organs and could prompt a sudden death due to major systemic failure (Cunningham, 2010).

Silent carriers of Alpha thalassemia lack signs or side effects of the disorder. Individuals affected by alpha or beta thalassemia disorders might have a slight iron deficiency. It might be an indication. Side effects might be more adverse in the expecting women, or the people with anxiety, or malnourished. Evidence may include fatigue. This might be the main side effect that a person with beta-thalassemia minor shows. Exhaustion is created by the diminished oxygen-conveying limit of the RBCs, bringing about reduced oxygenation for cells and tissues and causing pale skin tone due to insufficient oxygen in the blood (Bhatia et al., 2014).

Over the past three decades, regular blood transfusions have dramatically eliminated the complicity of thalassemia and bone marrow transplantation, enhanced the quality of life-permitting normal development throughout childhood and extended life span. But, transfusion results in a complication due to iron overload (Haidar et al., 2011).

Regular blood transfusion leads to iron overload-related complications including hormonal complications such as growth retardation, sexual immaturity, diabetes mellitus, and insufficiency of the parathyroid, thyroid, pituitary, adrenal glands, dilated myocardiopathy, liver fibrosis, and cirrhosis (Behera et al., 2014; Mokhtar et al., 2013; Goulas et al., 2012; Borgna-Pignatti and Gamberini, 2011).

In non-transfused thalassemic patients, the spleen, liver, heart, and bone marrow become significantly enlarged was stated before. Expansion of marrow cavities and thinning of cortices produce a variety of bone abnormalities in patients who are not optimally transfused (Bhatia et al., 2014). The result of bone biopsies from non-transfused thalassemic patients shows osteoporosis with increased bone resorption, decreased mineralization, and fewer bone-forming sites (Behera et al., 2014).

Over the past few decades, there has been a tremendous advancement in the field of clinical and genetics research. Many countries have nearly wiped out the disease by making better decisions like mass testing for hemoglobinopathies before marriage or childbirth. Thalassemia is now being considered to be treated beyond bone marrow transplantation which has always been the last hope to survive for a thalassemia patient. Today, allogeneic hematopoietic stem cell transplant (HSCT) from human leukocyte antigen (HLA)-matched sibling or other donors is the only treatment for thalassemia patients with $>90 \%$ transfusion independent survival rate in the patients transplanted with sibling matched donors. However, the treatment is possible in the individuals at a very young age. The disease-free survival rate depends upon the factors like HLA- matching, age and iron overloading etc. (Soni, 2020). Scientists have developed better tools to treat genetic disorders like stem cell technology and gene therapy to avoid tissue rejection in recipients. The therapy adds a corrective gene whose product combines with $\alpha$-globin to produce functional hemoglobin, thereby reversing the ineffective red blood cell production seen in $\beta$-thalassemia. However, the technique is much costly 
( $~ \$ 1.6$ billion) which could not be easy to afford by the patient's family or the healthcare providers (Harrison, 2019).

A novel CRISPR technology to edit faulty genes is a new game changer that showed promising results in disease models that made it a new hope to the diseased. The CRISPR(Clustered Regularly Interspaced Short Palindromic Repeats) along with the CRISPR- associated system, Cas (known as Crispr-Cas) is a powerful gene editing tool which has revolutionized the field of molecular biology in terms of gene therapies to treat hereditary genetic disorders (Lino et al., 2018). CRISPR Cas system enables programmable targeting of single base insertion or deletion (Indels) at a particular site of the genomic DNA. Frangoul et al. (2021) has successfully used the Crispr tool to edit the hematopoietic stem cells in order to downregulate the $\mathrm{B}$ globin gene to reduce the faulty beta globin chains and enhance the reactivation of fetal hemoglobin ( $G$ globin protein) to overcome the anemia eventually reducing the blood dependency in the thalassemia patients. The patients under trial were transplanted with these edited stem cells. The trial had shown promising results and no discrepancy has been reported so far.

\section{Acknowledgements}

We thank all our colleagues at the University of Sheffield, United Kingdom, King Abdulaziz University Jeddah Saudi Arabia, Women University of Azad Kashmir, Bagh Pakistan and University of Azad Jammu and Kashmir Muzaffarabad, Pakistan.

\section{References}

ALI, A.H.A.E., 2018. Normal reference values of some hematological parameters among adult sudanese people in elmatama locality. Republic of Sudan: Shendi University. Doctoral Dissertation in Haematology.

BEHERA, S., DIXIT, S., BULLIYYA, G. and KAR, S.K., 2014. Fat-soluble antioxidant vitamins, iron overload and chronic malnutrition in $\beta$-thalassemia major. Indian Journal of Pediatrics, vol. 81, no. 3, pp. 270-274. http://dx.doi.org/10.1007/s12098-013-1162-0. PMid:24062266.

BHATIA, M., JIN, Z., BAKER, C., GEYER, M.B., RADHAKRISHNAN, K., MORRIS, E., SATWANI, P., GEORGE, D., GARVIN, J., DEL TORO, G., ZUCKERMAN, W., LEE, M.T., LICURSI, M., HAWKS, R., SMILOW, E., BAXTER-LOWE, L.A., SCHWARTZ, J. and CAIRO, M.S., 2014. Reduced toxicity, myeloablative conditioning with $\mathrm{BU}$, fludarabine, alemtuzumab and SCT from sibling donors in children with sickle cell disease. Bone Marrow Transplantation, vol. 49, no. 7, pp. 913-920. http://dx.doi.org/10.1038/bmt.2014.84. PMid:24797180.

BIAGIOLI, M., PINTO, M., CESSELLI, D., ZANINELLO, M., LAZAREVIC, D., RONCAGLIA, P., SIMONE, R., VLACHOULI, C., PLESSY, C., BERTIN, N., BELTRAMI, A., KOBAYASHI, K., GALLO, V., SANTORO, C., FERRER, I., RIVELLA, S., BELTRAMI, C.A., CARNINCI, P., RAVIOLA, E. and GUSTINCICH, S., 2009. Unexpected expression of $\alpha$-and $\beta$-globin in mesencephalic dopaminergic neurons and glial cells. Proceedings of the National Academy of Sciences of the United States of America, vol. 106, no. 36, pp. 15454-15459. http://dx.doi.org/10.1073/pnas.0813216106. PMid:19717439.
BORGNA-PIGNATTI, C. and GAMBERINI, M.R., 2011. Complications of thalassemia major and their treatment. Expert Review of Hematology, vol. 4, no. 3, pp. 353-366. http://dx.doi.org/10.1586/ ehm.11.29. PMid:21668399.

BURMESTER, T. and HANKELN, T., 2014. Function and evolution of vertebrate globins. Acta Physiologica (Oxford, England), vol. 211, no. 3, pp. 501-514. http://dx.doi.org/10.1111/apha.12312. PMid:24811692.

CAMACHO, L.H., WILAIRATANA, P., WEISS, G., MERCADER, M.A., BRITTENHAM, G.M., LOOAREESUWAN, S. and GORDEUK, V.R., 1999. The eosinophilic response and haematological recovery after treatment for Plasmodium falciparum malaria. Tropical Medicine E'International Health, vol. 4, no. 7, pp. 471-475. http:// dx.doi.org/10.1046/j.1365-3156.1999.00426.x. PMid:10470337.

CAPPELLINI, M.D., COHEN, A., PORTER, J., TAHER, A. and VIPRAKASIT, V., 2014. Guidelines for the management of transfusion dependent thalassaemia (TDT). Nicosia, Cyprus: Thalassaemia International Federation, pp. 148-149.

CUNNINGHAM, M.J., 2010. Update on thalassemia: clinical care and complications. Hematology/Oncology Clinics of North America, vol. 24, no. 1, pp. 215-227. http://dx.doi.org/10.1016/j. hoc.2009.11.006. PMid:20113904.

DE SANCTIS, V., KATTAMIS, C., CANATAN, D., SOLIMAN, A.T., ELSEDFY, H., KARIMI, M., DAAR, S., WALI, Y., YASSIN, M., SOLIMAN, N., SOBTI, P., AL JAOUNI, S., EL KHOLY, M., FISCINA, B. and ANGASTINIOTIS, M., 2017. $\beta$-thalassemia distribution in the old world: an ancient disease seen from a historical standpoint. Mediterranean Journal of Hematology and Infectious Diseases, vol. 9, no. 1, pp. e2017018. http://dx.doi.org/10.4084/ mjhid.2017.018. PMid:28293406.

FIGUEIREDO, M.S., 2015. The importance of hemoglobin A2 determination. Revista Brasileira de Hematologia e Hemoterapia, vol. 37, no. 5, pp. 287-289. http://dx.doi.org/10.1016/j. bjhh.2015.06.002. PMid:26408359.

FRANGOUL, H., ALTSHULER, D., CAPPELLINI, M.D., CHEN, Y.S., DOMM, J., EUSTACE, B.K., FOELL, J., DE LA FUENTE, J., GRUPP, S., HANDGRETINGER, R., HO, T.W., KATTAMIS, A., KERNYTSKY, A., LEKSTROM-HIMES, J., LI, A.M., LOCATELLI, F., MAPARA, M.Y., DE MONTALEMBERT, M., RONDELLI, D., SHARMA, A., SHETH, S., SONI, S., STEINBERG, M.H., WALL, D., YEN, A. and CORBACIOGLU, S., 2021. CRISPR-Cas9 gene editing for sickle cell disease and $\beta$-thalassemia. The New England Journal of Medicine, vol. 384, no. 3, pp. 252-260. http://dx.doi.org/10.1056/NEJMoa2031054. PMid:33283989.

GIARDINE, B., BORG, J., VIENNAS, E., PAVLIDIS, C., MORADKHANI, K., JOLY, P., BARTSAKOULIA, M., RIEMER, C., MILLER, W., TZIMAS, G., WAJCMAN, H., HARDISON, R.C. and PATRINOS, G.P., 2014. Updates of the HbVar database of human hemoglobin variants and thalassemia mutations. Nucleic Acids Research, vol. 42, no. Database issue, pp. D1063-D1069. http://dx.doi.org/10.1093/ nar/gkt911. PMid:24137000.

GOULAS, V., KOURAKLI-SYMEONIDIS, A. and CAMOUTSIS, C., 2012. Comparative effects of three iron chelation therapies on the quality of life of greek patients with homozygous transfusion-dependent Beta-thalassemia. International Scholarly Research Notices, vol. 2012, pp. 139862. http://dx.doi. org/10.5402/2012/139862. PMid:23316378.

HAIDAR, R., MUSALLAM, K.M. and TAHER, A.T., 2011. Bone disease and skeletal complications in patients with $\beta$ thalassemia major. Bone, vol. 48, no. 3, pp. 425-432. http://dx.doi.org/10.1016/j. bone.2010.10.173. PMid:21035575.

HALEY, K., 2017. Congenital hemolytic anemia. Medicina Clínica, vol. 101, no. 2, pp. 361-374. http://dx.doi.org/10.1016/j. mcna.2016.09.008. PMid:28189176. 
HAMAMY, H.A. and AL-ALLAWI, N.A., 2013. Epidemiological profile of common haemoglobinopathies in Arab countries. Journal of Community Genetics, vol. 4, no. 2, pp. 147-167. http://dx.doi. org/10.1007/s12687-012-0127-8. PMid:23224852.

HARIHARAN, P., COLACO, S., COLAH, R., GHOSH, K. and NADKARNI, A., 2016. Delta globin gene variations leading to reduction in $\mathrm{HbA} 2$ levels. International Journal of Laboratory Hematology, vol. 38, no. 6, pp. 610-615. http://dx.doi.org/10.1111/ijlh.12548. PMid:27461962.

HARRISON, C., 2019. First gene therapy for $\beta$-thalassemia approved. Nature Biotechnology, vol. 37, no. 10, pp. 1102-1103. http://dx.doi. org/10.1038/d41587-019-00026-3. PMid:31578501.

HASSAN, F.M. and ALHAJOUJ, Z.Y., 2011. Hemoglobin variant in Al-Madina Al-Mnora City, Saudi Arabia. Pakistan Journal of Medical Research, vol. 50, no. 4, pp. 145.

HAY, D. and WEATHERALL, D.J., 2017. Thalassaemias. eLS, 1-6. In press. https://doi.org/10.1002/9780470015902.a0002274.pub3.

HUGHES, J.M.B. and PRIDE, N.B., 2012. Examination of the carbon monoxide diffusing capacity (DLCO) in relation to its KCO and VA components. American Journal of Respiratory and Critical Care Medicine, vol. 186, no. 2, pp. 132-139. http://dx.doi.org/10.1164/ rccm.201112-2160CI.

JHA, R. and JHA, S., 2014. Beta thalassemia-a review. Journal of Pathology of Nepal, vol. 4, no. 8, pp. 663-671. http://dx.doi. org/10.3126/jpn.v4i8.11609.

KAUFMAN, D.P., KHATTAR, J. and LAPPIN, S.L., 2021 [viewed 29 November 2020]. Physiology, fetal hemoglobin [online]. Treasure Island (FL): StatPearls. Available from: https://www.ncbi.nlm. nih.gov/books/NBK500011

KOHNE, E., 2011. Hemoglobinopathies: clinical manifestations, diagnosis, and treatment. Deutsches Ärzteblatt International, vol. 108, no. 31-32, pp. 532-540. http://dx.doi.org/10.3238/ arztebl.2011.0532. PMid:21886666.

LEE, S.T., YOO, E.H., KIM, J.Y., KIM, J.W. and KI, C.S., 2010. Multiplex ligation-dependent probe amplification screening of isolated increased $\mathrm{HbF}$ levels revealed three cases of novel rearrangements/deletions in the $\beta$-globin gene cluster. British Journal of Haematology, vol. 148, no. 1, pp. 154-160. http:// dx.doi.org/10.1111/j.1365-2141.2009.07927.x. PMid:19807730.

LEUNG, T.Y. and LAO, T.T., 2012. Thalassaemia in pregnancy. Best Practice \& Research. Clinical Obstetrics \& Gynaecology, vol. 26, no. 1, pp. 37-51. http://dx.doi.org/10.1016/j.bpobgyn.2011.10.009. PMid:22079388.

LINO, C.A., HARPER, J.C., CARNEY, J.P. and TIMLIN, J.A., 2018. Delivering CRISPR: a review of the challenges and approaches. Drug Delivery, vol. 25, no. 1, pp. 1234-1257. http://dx.doi.org/1 0.1080/10717544.2018.1474964. PMid:29801422.

LIPPI, G. and MATTIUZZI, C., 2020. Updated worldwide epidemiology of inherited erythrocyte disorders. Acta Haematologica, vol. 143, no. 3, pp. 196-203. http://dx.doi.org/10.1159/000502434. PMid:31550707.
MAIRBÄURL, H. and WEBER, R.E., 2012. Oxygen transport by hemoglobin. Comprehensive Physiology, vol. 2, no. 2, pp. 14631489. http://dx.doi.org/10.1002/cphy.c080113. PMid:23798307.

MEHDI, S.R. and AL DAHMASH, B.A., 2011. A comparative study of hematological parameters of $\alpha$ and $\beta$ thalassemias in a high prevalence zone: saudi Arabia. Indian Journal of Human Genetics, vol. 17, no. 3, pp. 207-211. http://dx.doi.org/10.4103/09716866.92106. PMid:22345994.

MEMON, A.S., MEMON, R., MUHAMMAD, A.T., ALI, S.A. and SIDDIQUI, A.J., 2017. Splenectomy: does it help in patients with thalassemia major. Journal of Liaquat University of Medical and Health Sciences, vol. 16, pp. 1-12. http://dx.doi.org/10.22442/ jlumhs.171610500.

MOKHTAR, G.M., GADALLAH, M., EL SHERIF, N.H. and ALI, H.T., 2013. Morbidities and mortality in transfusion-dependent beta-thalassemia patients (single-center experience). Pediatric Hematology and Oncology, vol. 30, no. 2, pp. 93-103. http:// dx.doi.org/10.3109/08880018.2012.752054. PMid:23301991.

MOLNAR, C. and GAIR, J., 2013. Transport of gases in human bodily fluids. In: C. MOLNAR and J. GAIR, eds. Concepts of Biology: 1st Canadian edition. Victoria: OpenStax College, chap. 20.4.

MUNCIE JUNIOR, H.L. and CAMPBELL, J.S., 2009. Alpha and beta thalassemia. American Family Physician, vol. 80, no. 4, pp. 339344. PMid:19678601.

QIN, X. and WU, J., 2009. Study on $\alpha$-thalassemia and hematological parameter in Li Nationality pregnant women in Hainan province. Zhongguo Fuyou Baojian, vol. 24, no. 32, pp. 4590-4592.

RACHMILEWITZ, E.A. and GIARDINA, P.J., 2011. How I treat thalassemia. Blood, vol. 118, no. 13, pp. 3479-3488. http:// dx.doi.org/10.1182/blood-2010-08-300335. PMid:21813448.

SONI, S., 2020. Gene therapies for transfusion dependent $\beta$ thalassemia: current status and critical criteria for success. American Journal of Hematology, vol. 95, no. 9, pp. 1099-1112. http://dx.doi.org/10.1002/ajh.25909. PMid:32562290.

TAHER, A.T. and CAPPELLINI, M.D., 2014. Management of nontransfusion-dependent thalassemia: a practical guide. Drugs, vol. 74, no. 15, pp. 1719-1729. http://dx.doi.org/10.1007/s40265014-0299-0. PMid:25255924.

TAHER, A.T., WEATHERALL, D.J. and CAPPELLINI, M.D., 2018. Thalassaemia. Lancet, vol. 391, no. 10116, pp. 155-167. http:// dx.doi.org/10.1016/S0140-6736(17)31822-6. PMid:28774421.

TAYLOR, S.M., PAROBEK, C.M. and FAIRHURST, R.M., 2012. Haemoglobinopathies and the clinical epidemiology of malaria: a systematic review and meta-analysis. The Lancet. Infectious Diseases, vol. 12, no. 6, pp. 457-468. http://dx.doi.org/10.1016/ S1473-3099(12)70055-5. PMid:22445352.

ZHAO, Y., LI, Y., CHEN, P., LI, S., LUO, J. and XIA, H., 2019. Performance comparison of blood collection tubes as liquid biopsy storage system for minimizing cf DNA contamination from genomic DNA. Journal of Clinical Laboratory Analysis, vol. 33, no. 2, pp. e22670. http://dx.doi.org/10.1002/jcla.22670. PMid:30191594. 